УдК 339.984

JEL classification: F00, F01, F02, F5,

F13

\section{Ольга МЕЛИХ}

кандидат економічних наук,

старший викладач,

кафедра міжнародних відносин,

Національний Університет

«Києво-Могилянська академія», Україна

E-mail: melykhov@ukma.edu.ua

ORCID iD: https://orcid.org/0000-0002-56030917

(C) Ольга Мелих, 2020

Отримано: 30.01.2020 p.

Прорецензовано: 09.02.2020 p.

Рекомендовано до друку: 26.02.2020 p.

Опубліковано: 28.02.2020 p

\section{(i) (3)}

Ця стаття розповсюджується на умовах ліцензії Creative Commons AttributionNonCommercial 4.0, яка дозволяє необмежене повторне використання, розповсюдження та відтворення на будь-якому носії, за умови правильного цитування оригінальної роботи.
Ольга Мелих (Україна)

\section{ПРОТЕКЦІОНІЗМ У ЄС: ВПЛИВ НА РИНКОВІ ВІДНОСИНИ 3 КРАЇНАМИ-ПАРТНЕРАМИ}

\begin{abstract}
АНОтАЦІя
У статті розглянуто теоретичні основи політики протекціонізму крізь призму визначення його індикаторів (маркерів). У процесі дослідження було становлено, що протекціонізм в країнах ЄС має неоднорідний характер та негативно впливає на ринкові, політичні та економічні відносини як між країнами-членами, так і на відносини із зовнішніми партнерами $Є C$. Окреслено причини застосування обмежуючих заходів та їх характер. Визначено ключові тенденції європейського протекціонізму, а також здійснено аналіз наслідків торговельних обмежень в контексті політичних та дипломатичних відносин між національними урядами країн-членів $Є C$ та країн-партнерів.
\end{abstract}

Мелих О. Протекціонізм у ЄС: вплив на ринкові відносини з країнамипартнерами. Економічний аналіз. 2020. Том 30. № 1. Частина 2. С. 91-99.

DOI: https://doi.org/10.35774/econa2020.01.02.091

Ключові слова: протекціонізм; тарифні обмеження; нетарифні обмеження; Європейський Союз; демпінг; економічна безпека; СОТ; економічні санкції. 
UDC 339.984

JEL classification: F00, F01, F02, F5, F13

\author{
Olga MELYKH \\ PhD in Economics, \\ Assistant Professor, \\ Department of International Relations, \\ National University of "Kyiv-Mohyla Academy", \\ Ukraine \\ E-mail: melykhov@ukma.edu.ua \\ ORCID iD: https://orcid.org/0000-0002-5603- \\ 0917
}

(C) Olga Melykh, 2020

Received: 30.01.2020

Revised: 09.02.2020

Accepted: 26.02.2020

Online publication date: 28.02 .2020

\section{cc) (1) \&}

This is an Open Access article, distributed under the terms of the Creative Commons AttributionNonCommercial 4.0 license, which permits unrestricted re-use, distribution, and reproduction in any medium, provided the original work is properly cited.
Olga Melykh (Ukraine)

\section{PROTECTIONISM IN THE EU: IMPACT ON MARKET RELATIONS WITH PARTNER COUNTRIES}

\begin{abstract}
The article describes theoretical foundations of protectionism policy through the prism of its indicators (markers). In this research it was found that protectionism in the EU countries is heterogeneous and negatively affects market, political and economic relations between member states and harm relations with external partners of the EU. The reasons for the application of restrictive measures and their nature are outlined. The key trends of European protectionism are determined, as well as the analysis of the consequences of trade restrictions in the context of political and diplomatic relations between national governments of the member states and partner countries.
\end{abstract}

Melykh, O. (2020). Protectionism in the EU: impact on market relations with partner countries. Economic analysis, 30 (1, Part 2), 91-99.

DOI: https://doi.org/10.35774/econa2020.01.02.091

Keywords: protectionism; tariff restrictions; non-tariff restrictions; European Union; dumping; economic security; WTO; economic sanctions.

\section{Вступ}

В епоху глобалізації, у час, коли світ перманентно перебуває в стані «рідкої (плинної) модерності» (термінологією британського соціолога 3. Баумана), пов'язаної 3 невизначеністю та непередбачуваністю розвитку глобальної системи, що, у свою чергу, закономірно випливає з глобалізаційних процесів, стрімкого розвитку інформаційно-комунікативних технологій (ІКТ), масової міграції, актуальності набуває проблема подальшого функціонування традиційної національної держави, ії економічних та політичних векторів розвитку.

Так, зокрема, у середовищі гіперглобалістів і трансформістів (К. Омае, Д. Сорос, У. Бек та ін.), як представників ключових течій модерних міжнародних відносин, прийнято вважати, що вищезазначені процеси підривають основи державності, зумовлюють розмивання національного суверенітету шляхом усе глибшої інтеграції держав у єдину систему, уніфікації їхнього політичного, економічного, соціального й культурного життя.

Окреслену ситуацію яскраво ілюструє Європа XXI століття, 28 країн якої репрезентовані на міжнародній арені єдиним глобальним актором - Європейським Союзом (ЄС). В умовах тісної співпраці європейські держави-члени $\in C$ виробляють спільну політику в різних сферах, у тому числі економічній. Оскільки метою будь-якої держави $€$ зростання добробуту своїх громадян, важливим стає питання вибору конкретних стратегій внутрішньота зовнішньоекономічного розвитку.

У цьому контексті, із точки зору історичної ретроспективи, сформувалося два основних діаметрально протилежних підходи: протекціонізм (від лат. protection - захист) та вільна торгівля, або фритредерство (від англ. free trade - вільна торгівля). Перший тип економічної політики (протекціонізм) орієнтовний на захист 
www.econa.org.ua

вітчизняного виробника від іноземної конкуренції шляхом залучення конкретних інструментів, тоді як другий тип (фритредерство) акцентує на ролі ринку, який, у свою чергу, має визначати структуру експорту та імпорту.

Очевидно, що обидва підходи мають як прибічників, так і критиків. У межах статті, перш за все, буде розглянуто політику протекціонізму, прибічники якого розглядають його як інструмент підвищення конкурентоспроможності товарів у межах національних i міжнародних ринків. У контексті цієї точки зору наголошується, що протекціонізм «не $\epsilon$ винаходом спекулятивних голів; він спричинений природним прагненням націй до самозбереження і до забезпечення свого добробуту та успіху або до встановлення переважання над іншими націями» [1].

Актуальність обраної теми зумовлена поширенням у межах європейської та світової спільноти дискурсу щодо втрати традиційними національними державами їхнього класичного базису та ролі на міжнародній арені у зв'язку з домінуванням наднаціональних інститутів та інституцій, які визначають ключові вектори політико-економічного розвитку, тим самим, підриваючи основи національного суверенітету. Крім цього, у ситуації рецесії світової економіки стрімко зростає політичний тиск виробників товарів і постачальників послуг на владні інститути з вимогою надати захист від імпортної конкуренції [2].

У такому випадку на порядку денному постає політика протекціонізму, одними з центральних соціально-політичних переваг якої $\epsilon$ підтримка державної безпеки країни та гарантування більш високого рівня життя [3].

Крім цього, згідно з останніми дослідженнями, світова фінансова криза призвела до різкого зростання протекціоністських заходів у світовій економіці. Головним чином, це стосується Європейського Союзу та США, які було названо «лідерами протекціонізму». «Наразі всі заголовки, пов'язані 3 протекціоністськими заходами в економіці, отримує Дональд Трамп, але насправді всі це роблять», - зазначив Девід Лоу, один із авторів дослідження. Так, понад 1000 «протекціоністських законів» дослідники виявили в законодавстві США та Євросоюзу [4].

\section{Мета та завдання статті}

Метою статті $€$ аналіз політики протекціонізму в межах Європейського Союзу в контексті її впливу на економічні відносини з країнами-партнерами. Таким чином, у межах статті ставимо перед собою наступні завдання: з'ясувати теоретичні аспекти політики протекціонізму, визначити ї̈ переваги i недоліки у площині глобальних викликів сьогодення; розглянути теоретичні основи політики протекціонізму крізь призму визначення його маркерів; визначити ключові тенденції європейського протекціонізму, а також здійснити аналіз наслідків торговельних обмежень в контексті політичних та дипломатичних відносин між національними урядами країн-членів $€ C$ та країнпартнерів

\section{Виклад основного матеріалу дослідження}

Протекціонізм як різновид економічної політики виник у той період, коли континентальну Європу охопила затяжна економічна депресія (7080-рр. XIX століття). Кризу вдалося подолати, однак керівництво тих країн, які під час депресії вдалися до протекціоністських заходів, помітили, що така політика дала їм змогу відчути стрімке промислове зростання, а отже, поліпшити соціальний та економічний добробут своїх громадян.

Відтоді й дотепер жодна держава світу, якою б ліберальною та демократичною вона не була, не обходиться без протекціоністських заходів у виробленні векторів своєї політики. В умовах глобалізованого світу складно, хоча й можливо, сповідувати принципи самоізоляції (до прикладу, Північна Корея), однак бути абсолютним адептом вільної торгівлі (фритредерства), бодай із точки зору захисту національного інтересу як головного мотиву, яким керується держава, - не є доцільним. у будь-якій державі уряд регулює міжнародний оборот ресурсів. Відкритість економіки в обов'язковому порядку передбачає врахування національного економічного інтересу [6].

Тобто мова йде, радше, про поєднання (із превалюванням одного з типів економічної політики) принципів протекціонізму та вільної торгівлі в умовах сучасного глобалізованого світу, аніж про екстремальне прийняття однієї з форм державної економічної політики. 3 огляду на це, питання про «кращість» використання (раціональність, ефективність, мінімізація втрат) однієї 3 двох стратегій (протекціонізму чи фритредерства) належить до розряду «вічних» дилем, яку намагаються розв'язати як економісти, так і політичні лідери.

3'ясування індикаторів (маркерів), які визначають політику протекціонізму, не видається можливим без дефініювання терміна. Так, протекціонізм позначають як «економічну політику держави, яка полягає в цілеспрямованому захисті внутрішнього ринку від надходження товарів іноземного виробництва» [7].

Цілеспрямований захист вітчизняного виробника здійснюється шляхом використання державними інститутами низки інструментів: імпортного та експортного мита, субсидій, квот, системи сертифікації та ін. Ці заходи випливають із усвідомлення того, що розвиток промисловості в 
www.econa.org.ua

межах країни залежить, у першу чергу, від стабільного й розвиненого внутрішнього ринку, а не від нестабільних викликів зовнішнього середовища [8].

Так, німецький економіст Ф. Ліст, який розвинув теорію протекціонізму, ще в XIX столітті зазначав: «Якби нації, які тільки почали створювати свою промисловість, неухильно слідували 6 доктрині вільної торгівлі, то в них були б знищені всі залишки промисловості, і вони потрапили 6 у «вічне підпорядкування» іноземній промисловій перевазі» [9].

Натомість, прихильники політики вільної торгівлі критикують протекціонізм за три ключові моменти:

- у довгостроковому періоді протекціонізм підриває основи національного виробництва, що, свою чергу, пов'язано з послабленням конкурентного тиску з боку світового ринку;

- знижує добробут споживачів: через введення протекціоністських заходів спостерігається зростання цін на товари;

- сприяє посиленню антагонізмів між державами, що створює загрозу стабільності та безпеки світового господарства [10].

Загалом, політика протекціонізму може переслідувати такі цілі:

- перманентний захист тих галузей і сфер виробництва, що мають стратегічно важливе для держави значення (до прикладу, сільське господарство), від іноземної конкуренції: так, у випадку завдання збитків цим галузям держава стає вразливою за умови військового конфлікту;

- тимчасовий захист тих галузей i сфер виробництва, які були утворені нещодавно, а отже, потребують часу на зміцнення з метою забезпечення конкурентоспроможності 3 аналогічними галузями й сферами інших держав;

- прийняття заходів у відповідь на проведення політики протекціонізму торговими партнерами (саме цей кейс $є$ важливим у випадку з Європейським Союзом, що діє як єдиний міжнароднийгравець).

Основним же завданням держави в особі їі уряду в контексті міжнародної торгівлі $\epsilon$, з одного боку, допомога експортерам вивезти якомога більше товарів, забезпечивши, при цьому, їхню конкурентоспроможність на зовнішньому ринку, а $з$ іншого боку, обмеження імпорту, що досягається шляхом зниження конкурентоспроможності іноземних товарів усередині конкретної держави, у межах її внутрішнього ринку.

Оскільки політики протекціонізму має на меті захищати національну економіку й стимулювати вітчизняного виробника товарів і постачальника послуг, важливими є питання щодо використання конкретних інструментів для досягнення своїх цілей. У випадку політики протекціонізму такими інструментами є різноманітні тарифні й нетарифні обмеження (сукупно їх також називають торговельними бар'єрами), на розмежуванні яких варто наголосити. Так, тарифні обмеження передбачають «сукупність методів державного регулювання зовнішньоторговельної діяльності, заснованих на застосуванні митних зборів, митних процедур і правил». Елементами тарифних обмежень, у свою чергу, є:

- митний тариф (як звід ставок митних зборів);

- митне декларування товарів, що переміщуються через митний кордон;

- митна процедура;

- товарна номенклатура зовнішньоекономічної діяльності (класифікатор товарів, що використовуються органами та учасниками зовнішньоекономічної діяльності 3 метою проведення митних операцій) [11].

Натомість, під нетарифними обмеженнями мають на увазі «сукупність методів державного регулювання зовнішньоекономічної діяльності, що мають на меті вплив на процеси у сфері зовнішньоекономічної діяльності, які не відносяться до митно-тарифних методів державного регулювання». До них, у свою чергу, належать:

- заходи прямого обмеження (ліцензування та квотування);

- спеціальні захисні заходи (імпортні квоти, спеціальні мита, антидемпінгові мита, встановлення бар'єру за мінімальними цінами на ринку країни-імпортера, компенсаційні мита);

- адміністративні та митні формальності (імпортні податки та збори, система сертифікації) [12].

Таким чином, частина методів державного регулювання орієнтована на захист внутрішнього ринку від іноземної конкуренції (у першу чергу, це стосується імпорту), тоді як інша група методів має на меті форсування експорту. Відповідно, ключові інструменти торговельної політики, які використовує держава, розміщено в таблиці 1.

Станом на сьогодні протекціонізм не втратив свого значення. Навпаки, у площині міжнародної політики все частіше можна почути твердження в бік деяких політиків і навіть цілих держав та їхніх об'єднань у посиленні протекціоністських заходів (наприклад, політика президента США Д. Трампа; посилення протекціонстських заходів у РФ, що зумовили звернення Євросоюзу до СОТ - Світова організація торгівлі), які в сучасних умовах зазвичай ототожнюють із прагненням ізолюватися, а отже, спалахами «надмірного» патріотизму, що в політичних категоріях пов'язують із ідеологічним консерватизмом. 
Таблиця 1. Класифікація інструментів торговельної політики [5]

\begin{tabular}{|c|c|c|c|}
\hline \multicolumn{2}{|c|}{ Методи } & Інструмент торговельної політики & Регулює переважно \\
\hline & Тарифнні & $\begin{array}{ll}\text { - } & \text { Митні збори } \\
\text { - } & \text { Митні квоти }\end{array}$ & $\begin{array}{ll}- & \text { Імпорт } \\
- & \text { Імпорт }\end{array}$ \\
\hline \multirow{3}{*}{$\begin{array}{l}\bar{I} \\
\theta \\
\Theta \\
\Xi \\
a \\
\varangle \\
\vdash \\
w \\
I\end{array}$} & Кількісні & $\begin{array}{ll}- & \text { Квотування } \\
- & \text { Ліцензування } \\
- & \text { «Добровільні обмеження» }\end{array}$ & $\begin{array}{ll}- & \text { Імпорт } \\
- & \text { Експорт-імпорт } \\
- & \text { Експорт } \\
\end{array}$ \\
\hline & Приховані & $\begin{array}{ll}\text { - } & \text { Державні закупівлі } \\
\text { - } & \text { Технічні бар'єри } \\
\text { - } & \text { Податки та збори } \\
\end{array}$ & $\begin{array}{ll}- & \text { Імпорт } \\
- & \text { Імпорт } \\
- & \text { Імпорт } \\
\end{array}$ \\
\hline & Фінансові & - Субсидії, кредитування & - Експорт \\
\hline
\end{tabular}

Так, наприклад, протекціонізм президента Дональда Трампа деякі аналітики називають головним ризиком для США. Так, більш ніж дві третини з 70 аналітиків, опитаних Reuters, заявили, що протекціоністська політика Д. Трампа виявилася найбільшою загрозою для найбільшої економіки у світі у 2017 році. «Немає жодних сумнівів, що очолює список ризиків можливість реалізації риторики, спрямованої проти вільної торгівлі», - зазначає Джим О'Салліван, відомий своїми прогнозами з економіки США [13].

що стосується іншого глобального міжнародного гравця - Європейського Союзу, - то розвиток інтеграційного об'єднання призвів до появи так званого колективного протекціонізму, що проводиться $Є С$ відносно третіх країн. Цю тезу яскраво ілюструє ситуація, яка сформувалася у відносинах між ЄС та Російською Федерацією внаслідок російської агресії в Україні, що, урештірешт, призвело до застосування санкцій та ембарго відносно Росії.

Отже, з'ясування ключових теоретичних аспектів здійснення політики протекціонізму дає нам змогу проаналізувати дію протекціонізму в практичній площині - на прикладі Європейського Союзу та його відносин із країнами-партнерами.

Особливості протекціонізму в країнах Європейського Союзу.

Для кращого розуміння масштабів явища протекціонізму ознайомимося 3 діаграмою на рис. 1, де представлені кількісні зміни у введені торговельних обмежень, що запроваджено країнами ЄС у хронологічному порядку [14].

Як видно з рис. 1, незважаючи на позитивну тенденцію у 2016-2017 роках, абсолютна кількість обмежень лишається високою.

Аналізуючи природу торгівельних обмежень країн Європейського Союзу, важливо зазначити, що природа сучасного європейського протекціонізму не $€$ однорідною і значно відрізняється залежно від причин, мети, стратегії та тактики реалізації обмежуючих методів.

Зокрема європейський протекціонізм має значні відмінності щодо мети застосування обмежуючих заходів.

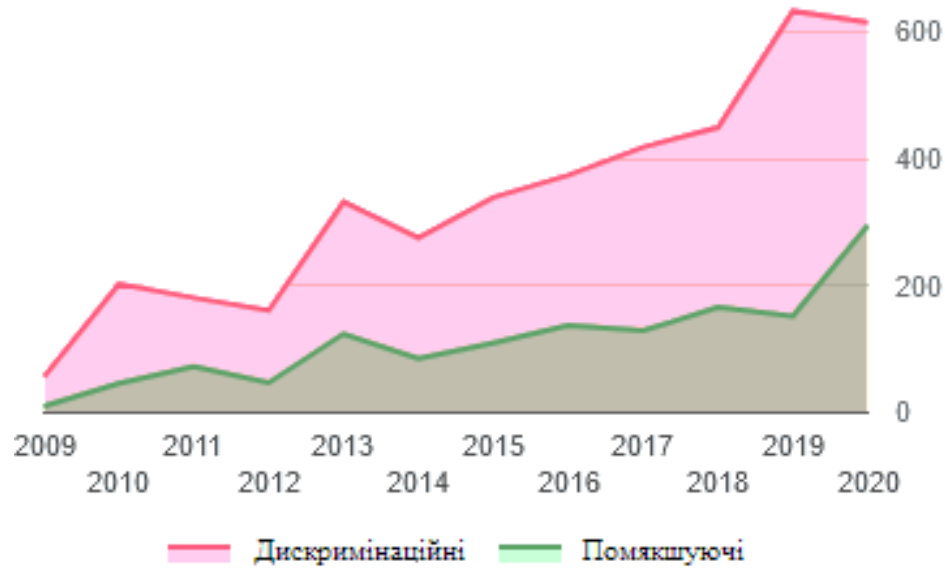

Рис. 1. Кількість обмежувальних заходів країн ЄС 2009-2020

Джерело: Global Trade Alert, http://www.globaltradealert.org. 
www.econa.org.ua

Так, як можна побачити із звіту Всесвітньої Організації Торгівлі, а також Global Trade Alert, обмежуючі заходи стосуються переважно країн, що розвиваються і які не є традиційними торговими партнерами ЄС. Мова йде, насамперед, про США та країни, що розвиваються. Ці заходи мають передусім профілактичний характер і мають на меті захистити ринки від агресивної інтервенції країн, що використовують методи демпінгу та прихованого протекціонізму, довести який в більшості випадків видається неможливим [15]. Саме тому в цьому контексті доцільніше використовувати термін "контр-протекціоністські заходи".

Для розуміння географічного розподілу обмежуючих заходів звернемось до рис. 2, на якому у вигляді карти світу зображено країни на які направлені протекціоністські та контрпротекціоністські заходи країн ЄС [14].

Яскравим прикладом таких мір, які отримали жорстку оцінку з боку СОТ та наукової спільноти стала ланцюгова реакція нетарифних обмежувальних заходів та збільшення обсягів підтримки національних економік країн-членів $€ C$, що мала місце в період глобальної фінансової кризи 2008-2009 і двох наступних років. Зокрема, національні уряди ЄС займались внутрішніми інвестиціями "стратегічно пріоритетних" галузей та підприємств в рамках підвищення національної безпеки, визначення яких досі залишається розмитим. Значно більший масштаб мало введення нетарифних обмежень, таких як санітарні обмеження, технічні бар'єри, введення систем обов'язкової реєстрації та ліцензування продукції та інші. (СОТ, ГТА) [14].

Проте, протекціонізм в країнах ЄC не обмежується лише контрзаходами щодо агресивних інтервенцій в європейську економічну систему. Так $€$ прецеденти, що ставлять загрозу непорозуміння та конфліктів поміж членами $\in C$.

Зокрема на рисунку 3 можна побачити вражаючі показники взаємообмежувальних заходів 28 країн ЄC.

Поступова лібералізація у міжєвропейських торгівельних відносинах намітилася лише у 20162017 роках, тим не менш, абсолютна кількість обмежень лишається високою і говорити про повну лібералізацію не доводиться.

Зокрема поширеними $€$ протекціоністські заходи з боку так званих "старих" країн-членів по відношенню до Балтійських та Східноєвропейських країн-членів. Переважно такі обмеження стосуються внутрішньої трудової міграції, харчової продукції та ринку перевезень.

Небезпеку також представляють протекціоністські тенденції, що пов'язують із сплеском популізму в Європі. Так, 23 жовтня 2017 за ініціативи Франції, Німеччини, Австрії та Данії міністри країн Євросоюзу домовилися про реформу правил, які визначають умови відрядження працівників всередині ЄС. Латвія разом з Польщею, Угорщиною та Литвою виступають категорично проти змін, стверджуючи, що вони знизять конкурентоспроможність їх підприємств при боротьбі за замовлення зі Старої Європи.
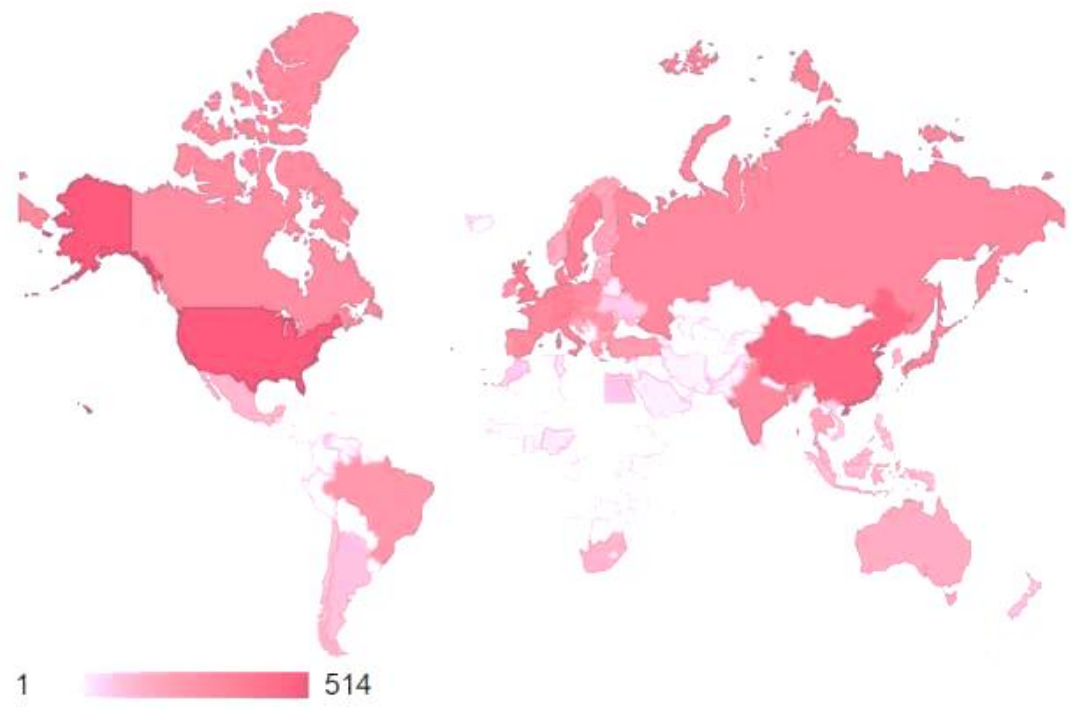

Рис. 2. Країни світу, що зазнали обмежувальних заходів країн-членів ЄС

Джерело: Global Trade Alert, http://www.globaltradealert.org. 


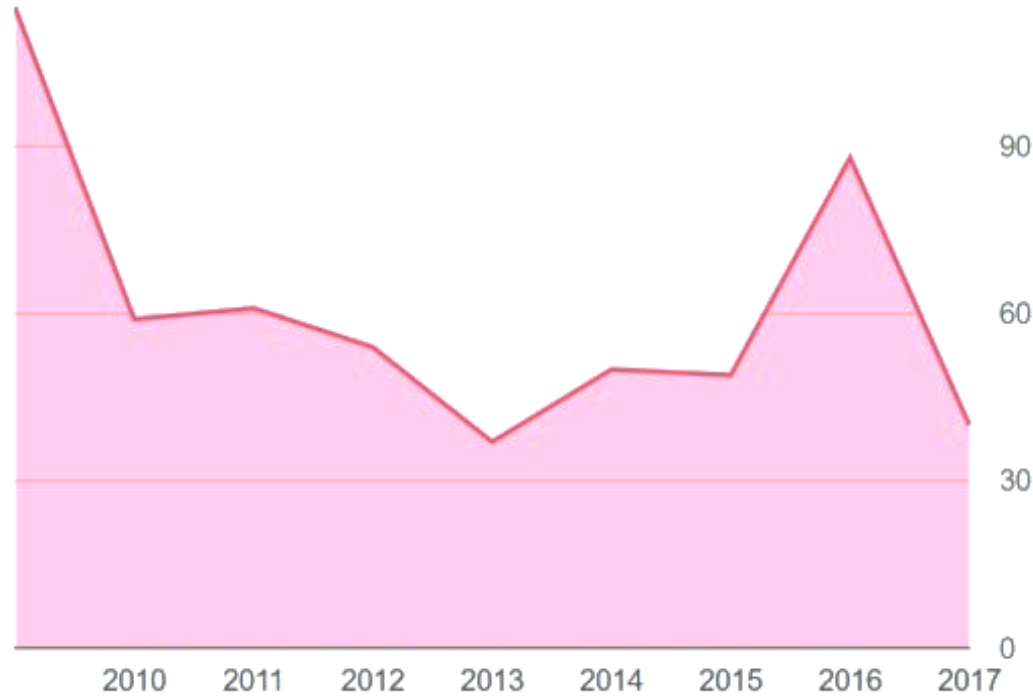

Рис. 3. Кількість взаємообмежувальних заходів країн ЄС 2009-2017

Джерело: Global Trade Alert, http://www.globaltradealert.org.

Зокрема парламентарій Латвії Р. Зіле в контексті обмеження ринку вантажних i пасажирських перевезень переконаний: "якщо ми втратимо цей 500-мільйонний ринок, як основу існування Європейського Союзу, то протиріччя між країнами стануть настільки гострими, що це буде загрожувати ЄС як проекту".

Більш того, у країни Балтії і Польща домовилися сформувати коаліцію, щоб активніше боротися проти нової директиви. "Ми 3 тривогою спостерігаємо на тенденцію до підриву підвалин EC, таких як чотири свободи єдиного ринку", заявила на зустрічі представників чотирьох країн прем'єр-міністр Польщі Беата Шидлов [17; 18].

Такі заходи не можуть не відображатись на політичних і дипломатичних відносинах поміж країнами-членами та країнами асоційованимичленами.

Зокрема показовим $€$ приклад України, уряд якої не отримав обіцяні раніше 600 мільйонів євро макрофінансової допомоги через відмову українського уряду скасувати мораторій на ліскругляк. ЄС апелює до того, що це порушує настанови СОТ і $€$ прямою підтримкою українським урядом місцевого деревообробного виробництва. Тим не менш, зважаючи на ультимативний характер вимоги скасувати мораторій, доцільніше казати про прихований протекціонізм з боку ЄС. Адже деревообробне виробництво в ЄС відчуває дефіцит в дешевій сировині і лісі,, який раніше стабільно постачався. В умовах мораторію на експорт українські виробники мають конкурентну перевагу на ринках ЄC [17].
Наслідки та тенденції протекціонізму в Європейському Союзі.

Враховуючи, що ринкова кон'юнктура в Європі не $\epsilon$ сталою та останнім часом змінюється, що демонструють зміни парадигми взаємовідносин $Є С$ та США, нової економічної політики Макрона, структурних змін в європейській економіці після виходу Британії зі складу ЄС, небезпека подальшого європейського сепаратизму.

Враховуючи зазначені складові та обмежену ефективність СОТ як органу, що покликаний мінімізувати сплески протекціонізму та сприяти відкритому ринку, варто очікувати збільшення ролі двосторонніх та регіональних угод, таких як DCFTA, CETA, CUFTA та інших [17].

Перевагою таких домовленостей $€$ їх більша гнучкість, оперативність та цільовий характер, на відміну від глобальних міжрегіональних угод. Подібні угоди відкриті до необмеженої кількості взаємних комбінацій i, на відміну від глобальних організацій та домовленостей, не несуть в собі небезпеку колізій та затягування переговорного процесу між країнами-підписантами. Справедливо зазначити, що подібні угоди можуть ефективно вирішити ключові проблеми торговельних відносин у ЄС та негативні наслідки протекціонізму як явища.

Отже, в контексті товарних відносин поміж країнами-членами Європейського союзу та їх партнерами спостерігається збільшення нетарифних форм протекціонізму, що пов'язано 3 бажанням обійти чіткі тарифні обмеження СОТ та уникнути подальших санкцій.

Зокрема нетарифні обмеження можуть мати подвійну мету, що називають «політикою заміщення» («policy substitution») і використовують, 
www.econa.org.ua

коли більш прозорі інструменти (таможні мита) недоступні, чи коли політики приховують свою мету.

Ще однією особливістю нетарифного регулювання є збільшення політичної складової, а саме сплеску популізму соціалістичного характеру в Європі, що пояснюється такими процесами як старіння нації та міграційною кризою.

Експерти СОТ розділяють нетарифні заходи на дві групи, виходячи з цілей застосування:

- спрямовані на підвищення добробуту населення, компенсуючі неефективність ринкових механізмів;

- спрямовані на досягнення політичних цілей, реалізацію інтересів певних політичних чи виробничих груп або споживачів.

Соціальні цілі, які при цьому забезпечуються включають: забезпечення національної безпеки, підтримка визначених моральних чи релігійних принципів, збереження соціальної згуртованості [18].

\section{Висновки і перспективи подальших досліджень}

Протекціонізм як явище має значне поширень в країнах Європейського союзу і має складний, неоднорідний характер. Загальний тренд обмежуючих заходів лишається спадаючим, проте говорити про суттєве скорочення найближчим часом не доводиться. До причин сучасного європейського протекціонізму відносять "захисні" або ж антикризові, структурні, політичні, соціальні і економічні фактори.

Останні тенденції відображають зміну характеру протекціонізму, а саме демонструють збільшення ролі нетарифних обмежень та прихованого протекціонізму, зокрема внутрішні інвестиції та підтримку національних виробників.

Протекціонізм як явище негативно впливає як на ринкові, політичні та економічні відносини між країнами-членами, так і на відносини із зовнішніми партнерами ЄC.

Негативні наслідки частково нівелюються правилами та санкціями СОТ, що доводить частково ефективність організації. В той час в контексті поширення заходів нетарифних обмежень все більшої популярності двосторонні та регіональні цільові домовленості.

В цілому ситуація 3 торговельними обмеженнями в Європейських країнах має позитивні прогнози, а проблема нової загрози протекціонізму потребує подальших досліджень як в економічному, так і в політичному контекстах.

\section{СПИСОК ВИКОРИСТАНИХ ДЖЕРЕЛ}

1. Global Trade Alert, http://www.globaltradealert.org.

2. World Trade Organization, https://www.wto.org

3. Глухих-Полещук Александра. Европа хочет запретить Латвии демпинговать на рынке труда. Каким образом? URL: http://rus.delfi.lv/news/daily/europ e/evropa-hochet- zapretit-latviidempingovat-na-rynke-truda-kakimobrazom. $d$ ? $i d=49374423$.

4. Голованова С. В. Нетарифные методы регулирования внешней торговли. ECM. URL: http://ecsocman.hse.ru/text/19211 913.

5. Гронтковська Г. Е., Ряба О. І., Венцурик А. М., Красновська О. Міжнародна економіка. навч. посіб. Київ: Центр учбової літератури, 2014. 384 с

6. Гютон Дж., Мартін К. Нові моделі торговельної політики на прикладі України, ЄС та Канади. VoxUkraine. URL:

https://voxukraine.org/2016/09/16/ new- patterns-in-trade-policy-ua.
7. Евросоюз пожаловался в ВТО на протекционизм со стороны Pocсии. Forbes. URL:

http://www.forbes.ru/news/223387 -evrosoyuz-pozhalovalsya-v-vto-naprotektsionizm-so-storony-rossii.

8. Исследование: США и ЕС лидеры «протекционизма». ИА REGNUM. URL: https://regnum.ru/news/2345269.h tml.

9. Погудаєва М. Ю, Жукова М. І. Современная политика протекционизма. Економіка. URL: http://economicarggu.ru/2010_3/ju kova.pdf.

10. Национальная политической

система

Економікс. URL: http://www.economics.kiev.ua/inde x.php?id=613\&view=article.

11. Невиконані обіцянки: Україна не отримає 600 млн євро від ЄС. ВВС Україна. URL: http://www.bbc.com/ukrainian/ne ws-42192270.

12. Протекционизм - угроза, которой надо противостоять всем миром. Інтернаціональний центр торговлі та сталого розвитку. URL:

(https://www.ictsd.org/downloads/ 2009/04/march-issue-mosty.pdf.
13. Протекционизм. Финансовій словарь. URL: https://dic.academic.ru/dic.nsf/fin_ enc/17166.

14. Середа В. И., Андреюк Н. В. Izvestiya of Saratov University. New Series. Series: Economics. Management. Law Известия Саратовского университета. 2013， 13(3-1), 327-334. URL: https://cyberleninka.ru/article/n/44 7478

15. Маркова Т. Протекционизм Свободная торговля. Центр Креативных Технологий. URL: https://www.inventech.ru/lib/macr o/macro-0060/.

16. Таможенно-

тарифное_регулирование_внешне торговой_деятельности. URL: https://customsexpert.ru/practicum /legal-entity/o-tamozhennomregulirovanii.htm.

17. Теории международной торговли. Сущность и структура международной торговли. Роль государства в международной торговле. URL: http://mrmarker.ru/p/page.php?id= 7222. 
www.econa.org.ua

18. Хуторов А., Строй А., Донич О

Конкурентоспособная Европа:

между равенством и

протекционизмом. URL:

http://Ir4.Ism.lv/lv/raksts/den-za-

dnem/konkurentosposobnaja-

evropa-mezhdu-ravenstvom-i-

protekcionizmom.a95375

\section{REFERENCES}

1. Global Trade Alert. Retrieved from http://www.globaltradealert.org.

2. World Trade Organization Retrieved from: https://www.wto.org

3. Hlukhykh-Poleshchuk, Aleksandra. (n.d.). Evropa khochet zapretyt Latvyy dempynhovat' na rynke truda. Kakym obrazom? Retrieved from:

http://rus.delfi.lv/news/daily/europ e/evropa-hochet- zapretit-latviidempingovat-na-rynke-truda-kakimobrazom. $d$ ? $i d=49374423$. Russian].

4. Holovanova, S. V. (n.d.). Netaryfnye metody rehulyrovaniya vneshney torhovli. ESM. Retrieved from: http://ecsocman.hse.ru/text/19211 913. [in Russian].

5. Hrontkovs'ka. H. E., Ryaba, O. I. Ventsuryk, A. M., \& Krasnovs'ka, O. I. (2014) Mizhnarodna ekonomika. Kyyiv: Tsentr uchbovoyi literatury. [in Ukrainian].

6. Hyuton Dzh., Martin K. (2016). Novi modeli torhovel'noyi polityky na prykladi Ukrayiny, YeS ta Kanady. VoxUkraine. Retrieved from: https://voxukraine.org/2016/09/16/ new- patterns-in-trade-policy-ua. [in Ukrainian].

7. Evrosoyuz pozhalovalsya v VTO na protektsyonyzm so storony Rossii. Forbes. Retrieved from: http://www.forbes.ru/news/223387 -evrosoyuz-pozhalovalsya-v-vto-naprotektsionizm-so-storony-rossii. [in Russian].
8. Yssledovanye: SShA y ES - lydery «protektsyonizma». YA REGNUM. Retrieved from: https://regnum.ru/news/2345269.h tml. [in Russian].

9. Pohudayeva, M. Yu, Zhukova M. I. (2010). Sovremennaya politika protektsionizma. Ekonomika. Retrieved from: http://economicarggu.ru/2010_3/ju kova.pdf. [in Russian].

10. Natsyonalnaya systema politicheskoy ekonomii. Ekonomiks. Retrieved from: http://www.economics.kiev.ua/inde x.php?id=613\&view=article. [in Russian].

11. Nevykonani obitsyanky: Ukrayina ne otrymaye $600 \mathrm{mln}$ yevro vid YeS. VVS Ukrayina. (n.d.). Retrieved from:

http://www.bbc.com/ukrainian/ne ws-42192270. [in Ukrainian].

12. Protektsyonyzm - uhroza, kotoroy nado protyvostoyat' vsem myrom. Internatsional'nyy tsentr torhovli ta staloho rozvytku. Retrieved from: https://www.ictsd.org/downloads/2 009/04/march-issue-mosty.pdf. [in Russian].

13. Protektsyonyzm. Fynansoviy slovar'. Retrieved from: https://dic.academic.ru/dic.nsf/fin enc/17166

14. Sereda, V. Y., \& Andreyuk, N. V. (2013). Izvestiya of Saratov University. New Series. Series: Economics. Management. Law Yzvestyya Saratovskoho unyversyteta. 2013, 13(3-1), 327334. Retrieved from: https://cyberleninka.ru/article/n/44 7478. [in Russian].
15. Markova, T. (n.d.). Protektsyonizm. Svobodnaya torhovlya. Tsentr Kreatyvnykh Tekhnolohiy. Retrieved from:

https://www.inventech.ru/lib/macr o/macro-0060/. [in Russian].

16. Tamozhennotaryfnoe_rehulyrovanye_vneshneto rhovoy deyatelnosty. Retrieved from:

https://customsexpert.ru/practicum /legal-entity/o-tamozhennomregulirovanii.htm. [in Russian]

17. Teorii mezhdunarodnoy torhovli. Sushchnost i struktura mezhdunarodnoy torhovlyi. Rol' hosudarstva $v$ mezhdunarodnoy torhovle. Retrieved from: http://mrmarker.ru/p/page.php?id= 7222. [in Russian].

18. Khutorov, A., Story, A., \& Donych, O (n.d.) Konkurentosposobnaya Evropa: mezhdu ravenstvom y protektsyonyzmom. Retrieved from: http://Ir4.Ism.lv/lv/raksts/den-zadnem/konkurentosposobnajaevropa-mezhdu-ravenstvom-iprotekcionizmom.a95375. 